Revue bibliographique pour le domaine irano-aryen

\title{
Maria Brosius. "No Reason to Hide: Women in the Neo-Elamite and Persian Periods"
}

Javier Álvarez-Mon

\section{(2) OpenEdition \\ 1 Journals}

\section{Electronic version}

URL: http://journals.openedition.org/abstractairanica/44842

DOI: 10.4000/abstractairanica.44842

ISBN: 1961-960X

ISSN: 1961-960X

Publisher:

CNRS (UMR 7528 Mondes iraniens et indiens), Éditions de l'IFRI

Electronic reference

Javier Álvarez-Mon, « Maria Brosius. "No Reason to Hide: Women in the Neo-Elamite and Persian Periods" », Abstracta Iranica [Online], Volume 37-38-39 | 2018, document 7, Online since 30 December 2018, connection on 27 September 2020. URL : http://journals.openedition.org/abstractairanica/ 44842 ; DOI : https://doi.org/10.4000/abstractairanica.44842

This text was automatically generated on 27 September 2020.

Tous droits réservés 


\title{
Maria Brosius. "No Reason to Hide: Women in the Neo-Elamite and Persian Periods"
}

\author{
Javier Álvarez-Mon
}

\section{REFERENCES}

Maria Brosius. "No Reason to Hide: Women in the Neo-Elamite and Persian Periods" in S. L. Budin and J. Macintosh Turfa (eds.). Women in Antiquity: Real Women Across the Ancient World. London -New York: Routledge, 2016, p. 156-74.

1 This article can be said to be a follow-up of Brosius' significant book on Women in Ancient Persia 559-331 BC (1996) where the author offered a revaluation of Greek sources, questioning their Hellenocentric perspectives, and stressed the importance of Iranian sources. Here Brosius expands this quest back in time to incorporate the local NeoElamite traditions, querying possible link between the courts of Elam and Persia. In "No Reason to Hide" the author suggests that women in the Elamite court were active public personae and most likely enjoyed economic wealth, and further indicates that their socio-political and economic status shaped some concepts of the role of women at the Persian court.

The section dedicated to Women in the Neo-Elamite introduces the reader to the extraordinary representations of Elamite queens manufactured in the second half of the second millennium BC in metalwork (Napir Asu) and monumental sculpture (Shekaft-e Salman I and II reliefs). However, the author offers some views of Elamite political history that are atypical, suggesting that over the centuries Elam came repeatedly under the control of Assyria, and other views that are not shared by all specialists, including the notion that after the destruction of Susa in 647 BC Elam broke down into petty kingdoms. For most commentators, the difference in date between the two reliefs depicting the royal family at Shekaft-e Salman and their inscriptions, and 
the controversial translation of the name captions added by Hanni have been a source of confusion, and this work reflects these difficulties. Furthermore, the small child depicted between the royal couple is a male, not a female as the author suggests (hence, most likely, an Elamite prince). For further information, see J. Álvarez-Mon, The Monumental Reliefs of the Elamite Highlands (2019).

\section{AUTHORS}

\section{JAVIER ÁLVAREZ-MON}

Department of Ancient History, Macquarie University, Australia 